Table.

\begin{tabular}{|c|c|c|c|c|c|}
\hline & & Robust & Pre-frail & Frail & p \\
\hline \multirow[t]{2}{*}{$\begin{array}{l}\text { Body mass } \\
\text { index }\left(\mathrm{kg} / \mathrm{m}^{2}\right)\end{array}$} & Knee OA & $\begin{array}{c}24.13 \\
{[23.74-24.53]}\end{array}$ & $\begin{array}{c}25.07 \\
{[24.83-25.32]}\end{array}$ & $\begin{array}{c}25.46 \\
{[25.14-25.78]}\end{array}$ & $<0.0001$ \\
\hline & RA & $23.73[23.04-24.42]$ & $\begin{array}{c}23.58 \\
{[23.20-23.97]}\end{array}$ & $\begin{array}{c}24.97 \\
{[24.28-25.66]}\end{array}$ & 0.001 \\
\hline \multirow[t]{2}{*}{$\begin{array}{l}\text { Hemoglobin, } \\
\text { g/dL }\end{array}$} & Knee OA & $\begin{array}{c}13.53 \\
{[13.36-13.70]}\end{array}$ & $\begin{array}{c}13.51 \\
{[13.42-13.61]}\end{array}$ & $\begin{array}{c}13.27 \\
{[13.14-13.40]}\end{array}$ & 0.004 \\
\hline & RA & $13.63[13.34-13.92$ & $\begin{array}{c}13.30 \\
{[13.14-13.46]}\end{array}$ & $\begin{array}{c}13.15 \\
{[12.85-13.45]}\end{array}$ & 0.060 \\
\hline \multirow[t]{2}{*}{$\begin{array}{l}\text { White blood cell, } \\
10^{3} / \mu \mathrm{L}\end{array}$} & Knee OA & $5.50[5.29-5.71]$ & $5.94[5.81-6.07]$ & 6.41 [6.24-6.58] & ]$<0.0001$ \\
\hline & RA & $5.47[5.13-5.82]$ & $5.85[5.64-6.06]$ & 6.68 [6.32-7.03] & $<0.0001$ \\
\hline \multirow[t]{2}{*}{ Platelet, $10^{3} / \mu \mathrm{L}$} & Knee OA & $\begin{array}{c}246.03 \\
{[238.52-253.53]}\end{array}$ & $\begin{array}{c}258.13 \\
{[253.44-262.82]}\end{array}$ & $\begin{array}{c}259.96 \\
{[253.40-266.53]}\end{array}$ & 0.045 \\
\hline & RA & $\begin{array}{c}237.49 \\
{[222.91-252.06]}\end{array}$ & $\begin{array}{c}255.30 \\
{[247.50-263.10]}\end{array}$ & $\begin{array}{c}262.04 \\
{[248.32-275.77]}\end{array}$ & 0.038 \\
\hline \multirow[t]{2}{*}{$\begin{array}{l}\text { Serum creati- } \\
\text { nine, } \mathrm{mg} / \mathrm{dL}\end{array}$} & Knee OA & $\begin{array}{c}0.734 \\
{[0.712-0.756]}\end{array}$ & $\begin{array}{c}0.764 \\
{[0.751-0.777]}\end{array}$ & $\begin{array}{c}0.861 \\
{[0.826-0.895]}\end{array}$ & $<0.0001$ \\
\hline & RA & $\begin{array}{c}0.732 \\
{[0.686-0.779]}\end{array}$ & $\begin{array}{c}0.783 \\
{[0.762-0.805]}\end{array}$ & $\begin{array}{c}0.917 \\
{[0.840-0.994]}\end{array}$ & $<0.0001$ \\
\hline \multirow[t]{2}{*}{$\begin{array}{l}\text { CKD-EPI eGFR, } \\
\mathrm{ml} / \mathrm{min}\end{array}$} & Knee OA & $\begin{array}{c}88.54 \\
{[86.77-90.31]}\end{array}$ & $\begin{array}{c}83.89 \\
{[82.89-84.88]}\end{array}$ & $\begin{array}{c}76.22 \\
{[74.80-77.63]}\end{array}$ & $<0.0001$ \\
\hline & RA & 94.30 [90.77-97.82] & $\begin{array}{c}85.86 \\
{[84.00-87.73]}\end{array}$ & $\begin{array}{c}74.76 \\
{[70.91-78.61]}\end{array}$ & $<0.0001$ \\
\hline \multirow[t]{2}{*}{ EQ-5D } & Knee OA & $\begin{array}{c}0.933 \\
{[0.921-0.944]}\end{array}$ & $\begin{array}{c}0.804 \\
{[0.793-0.815]}\end{array}$ & $\begin{array}{c}0.635 \\
{[0.616-0.653]}\end{array}$ & $<0.0001$ \\
\hline & RA & $\begin{array}{c}0.966 \\
{[0.953-0.979]}\end{array}$ & $\begin{array}{c}0.857 \\
{[0.839-0.874]}\end{array}$ & $\begin{array}{c}0.666[0.619 \\
-0.713]\end{array}$ & $<0.0001$ \\
\hline
\end{tabular}

Acknowledgments: None

Disclosure of Interests: None declared

DOI: 10.1136/annrheumdis-2020-eular.5182

\section{AB0867 INCREASED ADIPONECTIN LEVELS ARE ASSOCIATED WITH HIGHER RADIOGRAPHIC SCORES IN THE KNEE JOINT, BUT NOT IN THE HAND JOINT: THE DONG-GU STUDY}

J. H. Kang ${ }^{1}$, S. E. Choi ${ }^{1}$, H. Xu ${ }^{1}$, D. J. Park', S. S. Lee ${ }^{1}{ }^{1}$ Chonnam National University Medical School \& Hospital, Gwangju, Korea, Rep. of (South Korea)

Background: Several studies have evaluated the association between serum adiponectin levels and knee and hand osteoarthritis (OA), with mixed results.

Objectives: The aim of this study was to investigate the relationship between $\mathrm{OA}$ and serum adiponectin levels according to the radiographic features of knee and hand $\mathrm{OA}$.

Methods: A total of 2,402 subjects were recruited from the Dong-gu Study. Baseline characteristics were collected via a questionnaire, and X-rays of knee and hand joints were scored by a semi-quantitative grading system. The relationship between serum adiponectin levels and radiographic severity was evaluated by linear regression analysis.

Results: Subjects with higher tertiles of serum adiponectin were older and had a lower body mass index than those with lower tertiles. In the knee joint scores, serum adiponectin levels were positively associated with the total score $(P<0.001)$, osteophyte score $(P=0.003)$, and joint space narrowing (JSN) score $(P<0.001)$ among the three tertiles after adjustment for age, sex, body mass index, smoking, alcohol consumption, education, and physical activity. In the hand joint scores, no association was found between serum adiponectin levels and the total score, osteophyte score, JSN score, subchondral cyst score, sclerosis score, erosion score, and malalignment score among the three tertiles after adjustment.

Conclusion: In this study, we found that increased adiponectin levels were associated with higher radiographic scores in the knee joint, but not in the hand joint, suggesting different pathophysiologic mechanisms in the development of OA.

Disclosure of Interests: None declared

DOI: 10.1136/annrheumdis-2020-eular.1677

\section{AB0868 \\ EFFICACY AND SAFETY OF PULSED ELECTROMAGNETIC FIELDS IN THE TREATMENT OF OSTEOARTHRITIS: RESULTS OF A MULTICENTER BLIND PLACEBO-CONTROLLED STUDY.}

A. Karateev ${ }^{1}$, E. Pogozheva ${ }^{1}$, M. Sukhareva ${ }^{2}$, A. Lila ${ }^{2} .{ }^{1}$ Nasonova Research Institute of Rheumatology, Moscow, Russian Federation; ${ }^{2}$ Nasonova Research Institute of Rheumatology, Moscow, Russian Federation

Background: Pulsed electromagnetic fields (PEMF) is a well - known method of non-pharmacological treatment that is widely used in knee osteoarthritis (KOA). Objectives: To evaluate the effectiveness and safety of PEMF in KOA.

Methods: The study group consisted of $231 \mathrm{KOA}$ patients, $77.9 \%$ of women, age $61.9 \pm 12.2$ years, BMI $30.6 \pm 5.8 \mathrm{~kg} / \mathrm{m} 2$, average disease duration 5.0 [2.0;10.0] years. Patients were randomly assigned to two groups. Group 1 patients received PEMF for 14 days using a device that creates a low-frequency pulsed magnetic field, group 2-a false PEMF (a device that completely simulates a working device, but does not create a magnetic field). We evaluated the dynamics of the WOMAC index, the severity of pain at rest and when moving on a $100-\mathrm{mm}$ visual analog scale (VAS), the need for non-steroidal anti-inflammatory drugs (NSAIDs), and the evaluation of the patient's treatment result (on a 5-point scale).

Results: Statistically significant reduction in pain, stiffness, and improved function was observed in both true PEMF and false PEMF. Thus, the WOMAC pain in Group 1 decreased from 231 [180; 290] to 110 [60; 166.3], p<0.001; in Group 2 from 212.4 $[145 ; 260]$ to $143[76.5 ; 200], p<0.001$, the severity of pain in rest (VAS) decreased in Group 1 from 47 [27.8; 60] to $20[10 ; 30], p<0.001$; in Group 2 from 40 [20; 57.5] to 20 [7.5; 40], p<0.001. After therapy, the need for NSAIDs also decreased: in Group 1 NSAIDs were canceled or reduced in $33.1 \%$ of patients, in Group 2 - in $16.8 \%$ $(p=0.006)$. For all indicators, the dynamics were statistically more significant in Group 1 than in Group 2. The result of treatment as "good" and "excellent" was evaluated by $58.5 \%$ of patients in Group 1 and $39.8 \%$ of patients in Group 2, $p<0.001$. No serious adverse reactions were observed when using true and false PEMF. Two patients who received false PEMF therapy was interrupted due to increased joint pain.

Conclusion: PEMF with short-term use provides a significant improvement in the condition of KOA patients. PEMF is well tolerated and does not cause serious complications.

Disclosure of Interests: None declared

DOI: 10.1136/annrheumdis-2020-eular.3973

\section{AB0869 CLINICAL FEATURES OF WOMEN WITH KNEE OSTEOARTHRITIS AT DIAGNOSIS IN CAMEROON, SUB-SAHARAN AFRICA}

F. Kemta Lekpa ${ }^{1,2}$, A. Tidjong Kamkui ${ }^{3}$, H. Namme Luma ${ }^{3}$, S. P. Choukem ${ }^{1,2}$ ${ }^{1}$ Douala General Hospital, Internal Medicine, Douala, Cameroon; ${ }^{2}$ University of Dschang, Faculty of Medicine, Dschang, Cameroon; ${ }^{3}$ Douala General Hospital, Douala, Cameroon

Background: To the best of our knowledge, no study has been done in sub-Saharan Africa among those who suggest that knee osteoarthritis is more severe in women.

Objectives: To assess differences in features of knee osteoarthritis between female and male patients in a sub-Saharan Cameroonian population.

Methods: A cross-sectional study from December 2018 to April 2019 conducted in the Rheumatology Unit of the General Hospital, Douala, Cameroon. We included patients with a recent diagnosis of knee osteoarthritis according to 1986 ACR criteria and Kellgren-Lawrence radiographic grading $\geq 2$. Sociodemographic, clinical, radiographic and therapeutic data at diagnosis were collected. Assessment of the functional disability was done using the Lequesne algofunctional index more adapted to Africans than WOMAC index. We compared these data between women and men. A $p<0.05$ was considered to be statistically significant.

Results: We screened 168 patients with the diagnosis of knee osteoarthritis. Seventeen patients with Kellgren-Lawrence radiographic grading at 1 were excluded. Then, we included 151 patients (120 women and $31 \mathrm{men}$ ) in the final analysis. The main characteristics of patients at diagnosis are summarized in Table 1. Knee osteoarthritis in women was characterized by a low level of education, a low financial income, and a high frequency of obesity. There was no difference between women and men for age at diagnosis, place of residence, intensity of pain, functional disability, number of compartments of the affected knee, Kellgren-Lawrence radiographic grading, and treatment previously received. 